- Roberto Rozenberg

- Lygia da Veiga Pereira

\title{
The frequency of Tay-Sachs disese causing mutations in the Brazilian Jewish population justifies a carrier screening program
}

\author{
Laboratory of M olecular G enetics, D epartment of Biology/Genetics, \\ Institute of Biosciences, Universidade de São Paulo, São Paulo, Brazil
}

ABSTRACT

CONTEXT: Tay-Sachs disease is an autosomal reces sive disease characterized by progressive neurologic degeneration, fatal in early childhood In the Ashkenazi Jewish population the disease incidence is about 1 in every 3,500 newborns and the carrier frequency is 1 in every 29 individuals. Carrier screening programs for Tay-Sachs disease have reduced disease incidence by $90 \%$ in high-risk populations in several countries. The Brazilian Jewish population is estimated at 90,000 individuals. Currently, there is no screening program for Tay-Sachs disease in this population.

OBJ ECTIVE: To evaluate the importance of a Tay-Sachs disease carrier screening program in the Brazilian Jewish population by determining the frequency of heterozygotes and the acceptance of the pro gram by the community.

SETINNG: Laboratory of M olecular G enetics - Institute of Biosciences - Universidade de São Paulo.

PARTICIPANTS: 581 senior students from selected Jew ish high schools.

PROCEDURE: M olecular a nalysis of Tay-Sachs disease causing mutations by PCR amplification of genomic DN A, followed by restriction enzyme digestion.

RESULTS: Among 581 students that attended educational classes, $404(70 \%)$ elected to be tested for Tay-Sachs disease mutations. Of these, approximately $65 \%$ were of A shkenazi Jewish origin. Eight carriers were detected corresponding to a carrier frequency of 1 in every 33 individuals in the A shkenazi Jewish fraction of the sample.

CONCLUSION: The frequency of Tay-Sachs disease carriers among the Ashkenazi Jewish population of Brazil is similar to that of other countries where carrier screening programs have led to a significant decrease in disease incidence. Therefore, it is justifiable to implement a Tay-Sachs disease carrier screening program for the Brazilian Jewish population.

KEY WORDS: Tay-Sachs disease. G enetic screening HEXA gene. Jewish population. Molecular diag nosis.

\section{$\ldots \ldots \ldots$ INTRODUCTION}

Tay-Sachs disease is an autosomal recessive disease of lysosome storage characterized by progressive neurologic degeneration. ${ }^{1}$ Children affected by classic Tay-Sachs disease manifest the first symptoms at around 6 months and diebefore reaching 5 years of age. The clinical manifestations are particularly severeincluding deafness, blindness, dementia, and recurrent convulsions during theterminal stage when affected children are confined to bed. There is currently no treatment available.

Tay-Sachs disease is caused by mutations in the HEXA gene, located at 15q23-q24, which codes for the alpha subunit of the hexosaminidase $A$ enzyme. ${ }^{2,3}$ In the absence of the enzyme, its substrate, $G_{M_{2}}$ ganglioside, accumulates progressively in the neurons of the central nervous cortex leading to the clinical phenotype of the disease. Late-onset TaySachs disease (chronic form) is a rare variant phenotype with appearance of first symptoms during the second or third decade of life. ${ }^{4} \mathrm{~A}$ juvenile form is also distinguished, with an intermediate presentation. Theless severe phe notypes are due to residual enzyme activity. ${ }^{5}$

Asobserved for several recessivetraits, TaySachs disease incidence concentrates in some specific populations. That is the case for the Ashkenazi Jewish population (Jews of C entral or Eastern Europe descent), in which the disease incidence is 1 in every 3,500 newborns: approximately 100 times higher than in the general population. Among Ashkenazi Jews, 1 in every 29 individualsis heterozygous (asymptomatic) for Tay-Sachs disease causing mutations (here called carriers). ${ }^{6}$
Following the development of prenatal diagnosis for Tay-Sachs disease in the early 1970 's, ${ }^{7}$ most couples who had had an affected child chose to monitor subsequent pregnancies and bring to term only pregnancies of unaffected fetuses. 0 ther options for carrier couples include adoption, sperm or egg donation, pre-implantation diagnosis, reproductive abstention or simply taking their $25 \%$ risk.

Sinceonly couples with a previous affected child could beaware of their risk, carrier screening programs were massively initiated in the high-risk populations, aiming at detecting and informing carrier couples prior to any family history of the disease. These programs were made possible due to the development of an enzymatic assay that allowed the detection of heterozygotes for Tay-Sachs disease, 8,9

Up to 1992, over one million individuals had been tested for Tay-Sachs disease carrier status, more than 36,000 carriers had been detected and 1,054 carrier couples had been identified and informed of their risk prior to having an affected child. T hese programs led to a $90 \%$ decrease in the incidence of TaySachs disease in the Ashkenazi Jewish populations in the USA, Israel and C anada. ${ }^{10}$

M olecular diagnosis for Tay-Sachs disease in specific populations has presented a complementary or even alternativeway for performing enzymatic assay in detecting carriers. T hree mutations are responsible for $98 \%$ of the diseaseincidence in the Ashkenazi J ewish population. ${ }^{11,12} \mathrm{~A}$ 4-base pair insertion in exon 11 of the H EXA gene (InsTATC 1278) is present in $80 \%$ of Tay-Sachs disease, causing alleles. ${ }^{13} \mathrm{~T}$ he second most frequent mutation leading to TaySachs disease in Ashkenazi Jews is a guanine to 
cytosine transvertion in the first base of intron 12 (IVS12+1), and is present in $16 \%$ of the alleles. ${ }^{14,15}$ The third and most rare mutation, present in $2 \%$ of Tay-Sachs disease cases, is a guanine to adenine transition in the last nucleotide of exon 7 leading to a substitution of glycine for serine in position 269 of the alpha subunit of the hexosaminidase A enzyme (Gly269Ser). This last mutation leads to lateonset Tay-Sachs disease in the A shkenazi Jewish population. ${ }^{4,16}$

Brazil has the $8^{\text {th }}$ largest Jewish population in the world, counted as approximately 90,000 individuals in 1991. ${ }^{17}$ This work was designed to evaluate the need for and acceptance of a screening program for Tay-Sachs disease carriers in the Brazilian Jewish population. For that purpose, we evaluated the fre quency of carriers in a sample of this population and observed the reaction of the community to the proposal of a pilot screening program for Tay-Sachs disease carriers.

\section{.............. METHODS}

D uring the last three years, educational classes on Tay-Sachs disease were presented to senior students at fiveJ ewish high schools, three in the city of São Paulo (1998, 1999 and 2000) and two in the city of Rio de Janeiro (1999 and 2000). Theseinstitutions arethemain nonorthodox Jewish high schools of these cities. The students were 16 years of age and over, except for some participants from Colégio Liessin (2000), where the pre-senior class attended the program at the school's request.
After the presentation, studentstook home a consent form with a brief explanation of the program, the possible results of the test and a questionnairefor the parents. Thequestionnaire was aimed at evaluating the impact of similar programs from other countries (whether they would serve as an indication for Tay-Sachs disease testing among Brazilians), the ethnic origin of the students (Ashkenazi or not) and the acceptance of the program.

About a week later and with parents' consent, students who elected to be tested had mouth mucus collected by twirling a cotton swab on the inner cheek for a few seconds. The material was then taken to the laboratory where D N A was extracted according to Richards et al., 1993. ${ }^{18}$

D etection of mutations InsTAT C 1278, IVS12+1 and Gly269Ser was performed by PCR amplification of genomic D N A and subsequent digestion with restriction enzymes as described el sewhere. ${ }^{11}$

The results and their interpretation were confidentially sent by mail to thestudents. All samples and results wereidentified with codes so that a direct connection between student name and test result could not be made.

The carrier frequencies obtained were compared to those from other studies using Fisher's exact test. The statistical difference between two samples was considered nonsignificant when $\mathrm{P}>0.05$.

RESULTS

From 1998 to 2000, thirteen educational sessions were attended by 581 students. of thesestudents, 404 came to the screening sessions and delivered the consent form, an overall participation rate of $70 \%$.

Table 1 summarizes the participation rates by year in each school. Chi-squared analysis showed that the participation rates did not differ significantly among the schools ( $P=0.52)$, over the years $(P=0.22)$ and between the cities of São Paulo and Rio de Janeiro ( $P=0.71)$.

In order to access parents' opinions on the importance of the program, they were asked in the consent form: "H ow would you classify this program?". The results are shown in Table 2. The program was rated as "important", "very important" or "essential" in 95\% of the cases, among the parents of participating students.

In order to estimate the Ashkenazi fraction of the sample, we asked in the consent form about the possibility of Ashkenazi ancestry and the country of origin of the student's grandparents (data not shown). From these data it was readily apparent that $26 \%$ of the students had no Ashkenazi Jewish ancestry. For the remaining students, the grandparents' country of origin allowed us to estimate that $65 \%$ of the students' chromosomes were associated with Ashkenazi origin. This estimate is close to others previously established for the Brazilian Jewish population. ${ }^{19,20}$

Among the 404 participants, eight carriers were found. All thecarriers had Ashkenazi J ewish ancestry. Of the eight mutations detected, seven were InsTAT C 1278 and one was IVS12+1. This indicates a carrier frequency of 1 in every 51 students, similar to that observed in several Jewish populations $(P=0.16){ }^{10}$

$W$ hen the carrier frequency wasseparated by state, we found 7 carriers among 258 participants in São Paulo and 1 carrier among 146 participants in Rio de Janeiro. The difference in the carrier frequency between these two cities was not significant $(P=0.27)$.

\begin{tabular}{lll}
\hline $\begin{array}{l}\text { Table 2. Participants parents opinions } \\
\text { on the program }\end{array}$ \\
\hline \multicolumn{1}{|c}{ Opinion } & $\mathbf{n}$ & $\mathbf{( \% )}$ \\
\hline N egative & 0 & $0 \%$ \\
\hline Insignificant & 1 & $0 \%$ \\
\hline N ot very important & 5 & $1 \%$ \\
\hline Important & 184 & $28 \%$ \\
\hline Very important & 274 & $42 \%$ \\
\hline Essential & 165 & $25 \%$ \\
\hline N ot responded & 20 & $3 \%$ \\
\hline Total & $\mathbf{6 4 9}$ & $\mathbf{1 0 0} \%$ \\
\hline
\end{tabular}
(\%): percentage of the total number of answers (including non-respondents. 
When corrected for the Ashkenazi fraction of the sample, which comprised $65 \%$ of the 404 students' chromosomes, the estimated carrier frequency for Tay-Sachs disease is 1 in $33(8 / 263)$, similar to that observed in other Ashkenazi Jewish populations ( $P=0.87){ }^{6}$

D uring the study, threecarriers contacted the lab for re-testing and additional counseling. The mother of a carrier was also identified as a carrier.

\section{DISCUSSION}

O ne of the necessary prerequisites for the establishment of a carrier screening program for a recessive genetic disease is a high carrier frequency in the target population. It is also important to confirm the carrier frequency in similar populations from different countries since different migration patterns or different admixture rates could lead to populations with similar origin, but different carrier frequencies. For instance, the incidence of Tay-Sachs diseaseamong individuals of French-C anadian heritage living in northern $\mathrm{N}$ ew England (USA) is lower than that observed among thoseliving in Q uebec (C anada), downplaying the need for a screening program in the former. ${ }^{21}$

In contrast, the carrier frequency of TaySachs disease mutations in the Brazilian Jewish individualsherein studied is similar to that observed in the Jewish population of several other countries. The high carrier frequency found in the Brazilian Jewish population indicates the need of a screening program for Tay-Sachs disease in Brazil likethose effectively developed in other Jewish communities for over 30 years.

The 70\% participation rate shows good acceptance of the screening program by the community. This was also demonstrated by the participant's parents' rating of theprogram as "important", "very important" or "essential" in $95 \%$ of the cases, and the absence of a significant decrease in the participation rates in the years following the first presentations (Table 1). Among the factors that may have led to the high participation rate in our study were the participants' easy access to screening locations; a collection method that did not involve blood extraction; and finally, a higher knowledge of genetics in general due to the exposure in the media that the $\mathrm{H}$ uman $\mathrm{Ge}$ nome Project has had in recent years.

The Tay-Sachs disease screening program was the first to be performed for a genetic disease and served as a prototype for other preventive programs. ${ }^{23} \mathrm{C}$ urrently, over 50 centers in the world promote Tay-Sachs disease carrier screening. Although notable community mobilization has been obtained by some programs, others have not readily reached the same success. Such was the case in Canada, where researchers decided to move into the community institutions in order to reach participants instead of waiting for self-mobilization to screening centers.

The $C$ anadian Tay-Sachs disease program has been operating for over 20 years, screening senior high schools students and obtaining a similar participation rate $(67 \%)$ to the one in this study (70\%). ${ }^{23}$ Initially, its approach to screening faced the ethical controversy of testing single teenagers. ${ }^{24} \mathrm{~A}$ followup study of the program showed that most students had positive attitudes after screening and that both carriers and non-carriers considered the test during high school as not being premature. ${ }^{25} \mathrm{~T}$ he $\mathrm{C}$ anadian program served as a model for the research presented here, since two previous attempts to establish preventive programs in Brazil were discontinued. ${ }^{26,27}$ Before we directed it towards high schools, the offer of a screening program was made to different Jewish institutions. Although approval was obtained in some instances, the only institutions that presented a plausible approach to screening werethe nonorthodox Jewish high schools.

Besides the targeting of the screening, other ethical aspects were an essential part of this pilot program. In particular, we avoided stigmatization of carriers by focusing on delivering precise and comprehensive information about Tay-Sachs disease to students. Additionally, in order to maintain maximum confidentiality of test results, especially important in small communities, samples and results were coded, and the results were delivered to the participants by mail. T his procedure prevented the personal identification of carriers, even by researchers, unless they contacted the laboratory. M ost students $(91 \%)$ affirmed that they would prefer to get a positive result by mail rather than by a phone call.

$D$ ata from the consent form also indicated that the success of screening programs in other countries does not diminish the need for a program in Brazil. 0 nly $15 \%$ of students' parents affirmed they had relatives living in USA, I srael or C anada, the principal countries in which preventive programs are conducted. O nly $2 \%(11 / 651)$ of the parents had already been tested for TaySachs disease, none of whom because of recommendation by foreign relatives.
Finally, this was a pioneering piece of re search in that it exclusively used molecular diagnosis to detect Tay-Sachs disease carriers. It has corroborated the prediction that "the development of molecular diagnosisallows the performance of the D N A test in a small center without the need to maintain the rigorous quality control required for the enzyme assay". ${ }^{11}$ The molecular diagnosis also permits the tests to be performed on mouth mucus collection instead of requiring blood testing. H owever, while DNA test is adequate for A shkenazi Jews, the enzyme assay is more appropriate for the general population since different mutations may be present. ${ }^{28}$

In addition to the continuity of this screening program for Tay-Sachs disease carriers, an ideal outcome from this research would be to bring it to the attention of physicians assisting Brazilian Jewish couples that they may beattending aTay-Sachs disease carrier couple. It is important to note that the carrier frequency of Tay-Sachs disease among the general population isabout 10 times lower than in the population at risk, significantly diminishing but not eliminating Tay-Sachs disease among non-J ews. Recently, due to intermarriage and declining awareness of ancestry, screening has been recommended even for couples for whom only onemember is thought to have ancestry in a high-risk population. ${ }^{28}$ Screening can confirm or exclude the possibility of both members of a couple being TaySachs disease carriers, and is the best indication for prevention until an effective treatment becomes available for this disease.

.............. CONGLSION

The carrier frequency of the main muta tions causing Tay-Sachs disease in senior students of Jewish high schools was $1 / 51$. The corrected carrier frequency of Tay-Sachs disease in the Ashkenazi Jewish fraction of the sample was $1 / 33$, similar to that in Ashkenazi Jewish populations of other countries. The voluntary participation rate in a pilot screening program of Tay-Sachs disease in Jewish high schools between theyears 1998 and 2000 was $70 \%$.

Based on the efficiency of screening programs for Tay-Sachs disease in al erting carrier couples and decreasing the disease incidence in other countries, a similar program should beimplemented for the Brazilian Jewish population. In addition, physicians should recommend testing for Tay-Sachs disease mutations for individuals of Ashkenazi Jewish ancestry at reproductive age. 
1. Gravel RA, Clarke JT, Kaback M M, M ahuran D, Sandhoff $K$, Suzuki K. The $G_{M 2}$ gangliosidosis. In: Scriver $C R$, Beaudet AL, Sly WS, Valle DV, editors. The metabolic and molecular bases of inherited disease. $7^{\text {th }}$ ed., N ew York: M CGraw-H ill; 1995:2839-79

2. Takeda $\mathrm{K}, \mathrm{N}$ akai $\mathrm{H}, \mathrm{H}$ agiwara $\mathrm{H}$, et al. Fine assignment of beta hexosaminidase A alpha-subunit on 15q23-q24 by high-resolution in situ hybridization. TohokuJ Exp M ed 1990;160:203-11.

3. Nakai H, Byers M G, N owak NJ, Shows TB. Assignment of beta-hexosaminidase $\mathrm{A}$ alpha-subunit to human chromosomal region 15q23-q24. Cytogenet Cell Genet 1991;56:164

4. Navon R, ProiaRL. Themutationsin Ashkenazi Jews with adult $G_{M_{2}}$ gangliosidosis, the adult form of Tay-Sachs disease. Science 1989;243:1471-4.

5. Conzelmann E, Kytzia H - J, N avon R, Sandhoff K. G anglioside $\mathrm{G}_{\mathrm{M} 2} \mathrm{~N}$-acetyl-beta-D-hexosaminidase activity in cultured fibroblasts of late-infantileand adult $\mathrm{G}_{\mathrm{M}_{2}}$ gangliosidosis patients and of healthy probands with low hexosaminidase level. Am J H um Genet 1983;35:900-13.

6. Petersen GM , Rotter JI, C antor RM , et al. The Tay-Sachs disease gene in $\mathrm{N}$ orth American Jewish populations: geographic variations and origins. Am J Hum G enet 1983; 35:1258-69.

7. Schneck L, Valenti C, Amsterdam D, Friedland M, Adachi M, Volk BW. Prenatal diagnosis of Tay-Sachs disease. Lancet 1970;1:582-3.

8. O 'Brien JS, O kada S, Chen A, Fillerup D L. Tay-Sachs disease: detection of heterozygotes and homozygotes by serum hexosaminidase assay. N Engl J M ed 1970;283:15-20.

9. O 'Brien, JS, O kada S, Fillerup DL, Veath $M \mathrm{~L}$, Adornato BT, Brenner PH, Leroy JG. Tay-Sachs disease: prenatal diagnosis. Science 1971;172:61-4.

10. Kaback M M, Lim-Steele J, D abholkar D, Brown D, Levy N,
Zeiger K. Tay-Sachs disease - carrier screening, prenatal diagnosis, and themolecular era- an international perspective, 1970 to 1993. J Am M ed Assoc 1993; 270:2307-15.

11. Triggs-RaineB, Feingenbaum ASJ, N atowicz M R, et al. Screening for carriers of Tay-Sachs disease among Ashkenazi Jews: a comparison of D N A-based and enzyme-based tests. N ew Eng J Med 1990;323:6-12.

12. Fernandes M JG, Kaplan F, Clow CL, Hechtman P, Scriver CR Specificity and sensitivity of hexosaminidase assays and DNA analysis for the detection of Tay-Sachs disease gene carriers among Ashkenazi Jews. Genetic Epidemiology 1992; 9:16975 .

13. M yerowitz R, Costigan FC. Themajor defect in Ashkenazi Jews with Tay-Sachs disease is an insertion in the gene for the alphachain of beta-hexosaminidase. J Biol Chem 1988;263:18587-

14. Arpaia E, D umbrille-Ross A, M aler T, et al. Identification of an altered splice site in Ashkenazi Tay-Sachs disease. $\mathrm{N}$ ature 1988;333:85-6.

15. Ohno K, Suzuki K. A splicing defect due to an exon-intron junctional mutation results in abnormal beta-hexosaminidase al pha chain mRN Asin Ashkenazi Jewish patients with Tay-Sachs disease. Biochem Biophys Res Commun 1988;153:463-9.

16. Paw BH, Kaback M M, N eufeld EF. M olecular basis of adultonset and chronic $G_{M 2}$ gangliosidoses in patients of Ashkenazi Jewish origin: substitution of serine for glycine at position 269 of the alpha-subunit of beta-hexosaminidase. Proc $N$ at Acad Sci 1989;86:2413-7.

17. Instituto Brasileiro de G eografia eEstatística. Censo demográfico do Brasil, 1991. Rio de Janeiro: IBGE; 1992.

18. Richards B, Skoletsky J, Shuber AP, et al. M ultiplex PCR amplification from theCFTR geneusing D N A prepared from buc- cal brushes/swabs. Hum M ol Genet 1993;2:159-63.

19. Rattner $\mathrm{H}$. Tradição e mudança: a comunidade judaica em São Paulo. São Paulo: Ática; 1977:191.

20. Goodman RM. A perspective on genetic diseases among the Jewish people. In: Goodman RM, M otulsky AG, editors. Ge netic diseases among Ashkenazi Jews. N ew York: Raven Press; 1979:1-17.

21. Palomaki GE, W illiams J, H addowJE, N atowicz M R. Tay-Sachs diseasein persons of French- $C$ anadian heritage in northern $\mathrm{N}$ ew England. Am J M ed Genet 1995;56:409-12.

22. Blitzer M G, M CD owell GA. Tay-Sachs disease as a model for screening inborn errors. Clin Lab M ed 1992;12:463-80.

23. M itchell IJ, Capua A, Clow C, Scriver CR. Twenty-year outcome analysis of genetic screening programs for Tay-Sachs and b-Thalassemia disease carriersin high schools. Am J H um G enet 1996;59:793-98.

24. Levin, M. Screening Jews and Genes: A consideration of the ethics of genetic screening within the Jewish community: challenges and responses. Genetic Testing; 1999;3:207-213.

25. Zeesman S, Clow CL, Cartier L, Scriver CR. A private view of heterozigozity: eight-year follow-up study of theTay-Sachs gene detected by high school screening in M ontreal. Am J M ed G enet 1984;18:769-78.

26. Buchalter M S, Wannmacher CM D, Wajner M. Tay-Sachs disease: screening and prevention program in Porto Alegre. Rev Brasil Genet VI 1983;3:539-47.

27. Schmidt JS, Diament AJ, Krynski S, Kamei ME, Rodrigues $M M$, Takata $S$. Detección de errores congénitos de metabolismo en San Pablo, Brasil. Bol M éd H osp Infant M éx 1981;38:217-29

28. Kaplan F. Tay-Sachs disease carrier screening: a model for pre vention of genetic disease. Genetic Testing 1998:4:271-92.
..Publ ish ing in for mat io n .

Acknowledgments. The authors wish to thank $L$. Pelleg from the Israeli Tay-Sachs disease test center and R. Desnick, R. Kornreich and C. Eng from M ount Sinai Hospital (N Y) for the positive control samples obtained. We also wish to thank the boards of the participating schools and CN Pq and FAPESP for financial support

Roberto Rozenberg, MSc. Department of G enetics, Institute of Biosciences, Universidade de São Paulo, São Paulo, Brazil.

Lygia da Veiga Pereira, PhD. Department of Biology, Institute of Biosciences, Universidade de São Paulo, São Paulo, Brazil.

Sources of funding: $C N P q$ and FAPESP n० 98/ 02435-2 Conflict of interest: $\mathrm{N}$ ot declared Last received: 20 February 2001

Accepted: 20 A pril 2001

Address for correspondence

Lygia da Veiga Pereira

Departamento de Biologia, Instituto de Biociências,

Universidade de São Paulo

Rua do Matão, 277/350

São Paulo/ SP - Brazil - CEP 05508-900

E-mail: Ipereira@usp.br
. .

RESUMO

CONTEXTO: A doença de Tay-Sachs é uma doença autossômica recessiva caracterizada por uma degeneração neurológica progressiva, fatal na primeira infância. $\mathrm{Na}$ população judaica Ashkenazita a incidência da doença é de um para cada $\mathbf{3 . 5 0 0}$ nascimentos, e a freqüência de portadores é de um para cada 29 indivíduos. Programas de triagem de portadores da doença de TaySachs reduziram a incidência da doença em $90 \%$ nas populações em risco de diversos países. A população judaica brasileira é estimada em 90.000 indivíduos. Atualmente não há programa de triagem populacional da doença de Tay-Sachs nessa população.

OBJETIVO: Avaliar a importância de um programa detriagem de portadores da doença deTay-Sachsna população judaica brasileira, através do estabelecimento da freqüência de portadores eda aceitação desse programa pela comunidade

LOCAL: Laboratório de genética molecular, Instituto deBiociências, U niversidade deSão Paulo.

PARTICIPANTES: 581 alunos do $3^{\circ}$. ano do ensino médio de escolasjudaicas selecionadas.

PROCEDIMENTOS: Análise molecular de mutações causadoras da doença deTay-Sachs através de amplificação de D N A genômico por PCR e digestão por enzimas de restrição.

RESULTAD OS: Entre 581 alunos que assistiram palestras informativas, $404(70 \%)$ decidiram realizar o teste para detecção de portadores. D esses, aproximadamente $65 \%$ tinham origem judaica Ashkenazita. O ito portadores foram identificadoscorrespondendo a uma freqüência de portadores de um em cada 33 indivíduosna fração judaica Ashkenazita da amostra.

CON CLUSÕ ES: A freqüência de portadores da doença de Tay-Sachs, na população judaica Ashkenazita brasileira, é similar àquela de outros países nos quais programas de triagem levaram a uma redução significativa na incidência da doença. Assim, é justificável a implementação de um programa de triagem de portadores da doença de Tay-Sachs na população judaica brasileira.

PALAVRAS-C H AVE: D oença de Tay-Sachs. Triagem genética. G ene H EXA. População judaica. Diagnóstico molecular. 